\title{
Sundanese Language Politeness as a Local Wisdom in the Industrial Revolution Era 4.0
}

\author{
Y Sudaryat ${ }^{1}$, Rahman ${ }^{2}$ \\ \{1yayat.sudaryat@upi.edu, ${ }^{2}$ rahman@upi.edu $\}$ \\ ${ }^{1,2}$ Universitas Pendidikan Indonesia, Bandung, Indonesia
}

\begin{abstract}
The fact shows that one of the cultural forms of the archipelago that belongs to the Sundanese community is politeness in language. Many speakers of Sundanese are deviant in the use of language politeness, whereas in politeness, the value of local wisdom is stored which can be used to deal with the Industrial Revolution Era 4.0. This study aims to explain the problems and the results of repositioning Sundanese language politeness in the Industrial Revolution Era 4.0. In this study a qualitative approach with descriptive methods was used. The research data in the form of cases of use of Sundanese politeness were collected by intuition techniques, documentation techniques, and observation techniques. Data analysis uses immediate constituent analysis. The language elements described in this study are Sundanese-language politeness related to pronunciation, word formation, sentence arrangement, interpretation of word meanings, and socio-pragmatic contexts. From the results of this study, it is expected to obtain a comprehensive explanation of the current situation of Sundanese language politeness and the repositioning of Sundanese language politeness rules that include phonological levels, grammatical, lexico-semantic levels, and socio-pragmatic levels.
\end{abstract}

Keywords: Language Politeness, Local Wisdom, Socio-pragmatics, Grammar, Lexico-semantics, Industrial Revolution era 4.0

\section{INTRODUCTION}

Politeness language (language ettiquete) relating to the use of polite language, i.e. the use of a variety of a language system (smooth, medium, and coarse) with the relevant power, position (social status) and familiarity ( solidarity), as well as the relationship between the role of the speaker and his speech [1]. Politeness language should be in accordance with the rules of the linguistic and socio-pragmatic rule. Rules of politeness related to phonological rules, the rules of grammatical (morphological and syntactic rules), as well as rule lexico-semantic difference. The socio-pragmatic rules concerning the issue of sociological rules and pragmatic rules such as the relationship between addresser and adressee, the language situation, language background, and language diversity.

In the use of Sundanese language politeness found several problems, among other things, (1) many Sundanese language speakers the wrong use of politeness language; (2) the emergence of new word pairs that violates the rules of Sundanese language; and (3) the use of animal words in the spoken language communication. 
Politeness language into local wisdom that refers to all forms of knowledge, beliefs, understandings, and insights as well as a customs ethics that guide human behaviour in life. The

entire local wisdom must be lived, practiced, taught, and passed down from one generation to the

next as well as forming a pattern of daily human behavior [2]. Local wisdom can be reflected in the expression language, among other things, in the politeness language.

The Sundanese language politeness is one of the riches of the Sundanese culture has also become a cultural wealth of the archipelago. Cultures of the area still owned, maintained, and developed by the community supporters. However, lately, a sense of belonging as well as the efforts of maintaining and developing the cultures of the area on the wane. This is due to the influence of the current new globalisation and modernisation, including the situation in the Era of the industrial revolution 4.0. Indeed, we realize that modernization and globalization had positive and negative values. A positive value can be utilized in the life of society, whereas a negative value can serve as a mirror of life.

In Sundanese language usage language politeness still found, though there were a few cases of irregularities. The high value of local wisdom will not be useful for the life of the nation if it is not studied, interpreted, and formulated as well as utilized for the development of the nation. One effort in that direction is to study the politeness Sundanese. Research on such matters rarely done due to things long considered less good compared to things new and modern, but many great values that can be excavated as well as very useful for nation building, among other things, it contains philosophical values of life as local wisdom.

This paper aims to expose local wisdom values are implied as well as express politeness in Sundanese. Local wisdom values obtained through the exposure situation and rules of use of politeness Sundanese associated with phonological level, syntactic level, lexico-semantic difference, and the socio-pragmatic level.

Language politeness or language ettiquete relating to the use of polite language, i.e. the use of a variety of a language system (smooth, medium, and coarse) with the relevant power, position (social status) and familiarity (solidarity), as well as the relationship between the role of the speaker and his speech [1]. Politeness language should be in accordance with the rules of the linguistic and socio-pragmatic rule. Rules of politeness related to phonological rules, the rules of grammatical (morphological and syntactic rules), as well as rule lexico-semantic difference. The socio-pragmatic rules concerning the issue of sociological rules and pragmatic rules such as the relationship between addresser and adressee, the language situation, language background, and language diversity.

In the use of Sundanese language politeness found several problems, among other things, (1) many Sundanese language speakers the wrong use of politeness language; (2) the emergence of new word pairs that violates the rules of Sundanese language; and (3) the use of animal words in the spoken language communication.

Politeness language into local wisdom that refers to all forms of knowledge, beliefs, understandings, and insights as well as a customs ethics that guide human behaviour in life. The entire local wisdom must be lived, practiced, taught, and passed down from one generation to the next as well as forming a pattern of daily human behavior [2]. Local wisdom can be reflected in the expression language, among other things, in the language politeness.

The Sundanese language politeness is one of the riches of the Sundanese culture has also become a cultural wealth of the archipelago. Cultures of the area still owned, maintained, and developed by the community supporters. However, lately, a sense of belonging as well as the efforts of maintaining and developing the cultures of the area on the wane. This is due to the 
influence of the current new globalisation and modernisation, including the situation in the Era of the industrial revolution 4.0. Indeed we realize that modernization and globalization had positive and negative values. A positive value can be utilized in the life of society, whereas a negative value can serve as a mirror of life.

In Sundanese language usage language politeness still found, though there were a few cases of irregularities. The high value of local wisdom will not be useful for the life of the nation if it is not studied, interpreted, and formulated as well as utilized for the development of the nation. One effort in that direction is to study the Sundanese politeness. Research on such matters rarely done due to things long considered less good compared to things new and modern, but many great values that can be excavated as well as very useful for nation building, among other things, it contains philosophical values of life as local wisdom.

This paper aims to expose local wisdom values are implied as well as express politeness in Sundanese. Local wisdom values obtained through the exposure situation and rules of use of politeness Sundanese associated with phonological level, syntactic level, lexico-semantic difference, and the socio-pragmatic level.

\section{RESEARCH METHOD}

This research uses qualitative descriptive method of approach because the data collected and analyzed more qualitative in nature. Qualitative research is research conducted on the condition because naturalistic natural (natural setting). Natural objects are objects that are developed for what it is, not manipulated by the researchers and the presence of the researcher does not affect dynamics on the object. The language elements described in this research is the form of elements of Sundanese language politeness with regard to pronunciation, word formation, sentence structuring, the interpretation of the meaning of the word, and the context socio-pragmatic.

Research data in the form of politeness language use cases were collected with engineering, technical documentation, intuition and observation techniques. The techniques used to collect intuition politeness Sundanese of researchers itself. Engineering documentation used to obtain data from the Sundanese politeness written sources, whereas the observation techniques used to obtain data from users of Sundanese language, politeness language. Determination of language diversity wrote this based on the consideration that (a) the range of writing more preserved than oral variety so that it reflects a planned language, steady, and raw [3], and (b) the Sundanese language has a standard writing systems. [4] The Sundanese language politeness data using the immediate constituent (IC) analysis techniques. Elements of language politeness that analyzed the factors related to the linguistic (phonological, grammatical, lexico-semantic difference, and the socio-pragmatic) and non-linguistic factors (follow the Horn or gestures and facial). In addition to the written data source, the data source is used orally in the form of intuition researchers. This is possible because any researchers including native speakers of language. Researchers can make Sundanese language politeness dat.

\section{RESULTS AND DISCUSSION}

Politeness or etiquette is the settings, custom, or practice in force in the community. Politeness is a defined behavior rules and agreed jointly by a particular society so politeness at once become a precondition agreed by social behavior. [5] Therefore, politeness is commonly called "tatakrama", i.e. customs or manners in tata to behave and act in the association the 
right think so as not to violate the mistaken and benchmark who has become the acting habit patterns commendable. [6]

One type of politeness is language politeness (tatakrama bahasa), i.e. the use of a variety of a language system (rough, medium, and respectful) with the relevant power, position (social status) and familiarity (solidarity), as well as the relationship between the role of the speaker and speaking partners. [7]

Language politeness is reflected in procedures communicated through sign language or verbal procedures. When communicating, we are subject to cultural norms, not merely convey the ideas that we think. Language setting must be accordance with the cultural elements that exist in the community where they lice and use a language in communication. When a person's language setting incompatible with cultural norms, then he will get a negative value, for example, accused as being arrogant, imperious, nonchalance, selfish, immoral, and uncultured.

The current situation is quite alarming because users often use the Sundanese language politeness rules speak Sundanese. Errors that are often found in the selection of the words manners (smooth). Sundanese language users often use polite words for others (P-2 and P-3) is used for yourself (P-1). As an example consider the following data.

(01) Punten Ibu uihan deui, henteu kadangu.

'[Sorry Mom could be retried, nothing I have heard].'

(02) Antosan heula Kang, abdi badé siram heula, tadi gugahna kasiangan. '[Wait a minute my brothers. I'd like to take a bath first, last I wake up sleeping through.]'

On the data above seem the use of language politeness when speaking (P-1) communicating with partners said (P-2) using smooth words for others, namely the words kadangu and gugah as well as a flush. The word kadangu is a fine word for said partners (P-2), whereas for yourself (P-1) should use the word subtle kakuping. The word flush and gugah both of which are smooth to partner said (P-2) or to the person who is told (P-3), whereas for yourself (P-1) should use the word delicate mandi 'bath' and hudang 'bath'. Thus, the sentence (01) and (02) should be expressed as in sentence (03) and (04) as follows.

(03) Punten Ibu uihan deui, henteu kakuping. '[Sorry Mom could be retried, nothing I have heard].'

(04) Antosan heula Kang, abdi badé mandi heula, tadi hudangna kasiangan.

'[Wait a minute my brothers. I'd like to take a bath first, last I wake up sleeping through.]'

There are also polite words for speakers $(\mathrm{P}-1)$ is used for others (P-2 and $\mathrm{P}-3)$. Consider the following data.

(05) Dupi Tétéh wangsul ti mana?

'[My sister, where you came from?]'

(06) Dupi Bapa parantos neda?

'[Have you eaten?]'

On the data (05) and (6) above seem the use of politeness language when speaking (P-1) communicating with partners said (P-2) using smooth words for speakers (P-1), i.e. the words wangsul 'come back home 'and neda 'eat'. The word wangsul is a fine word for speakers (P1 ), whereas for the partner said (P-2) must use the word subtle mulih 'come back home'. The 
word neda is a fine word for speakers (P-1), whereas for the partner said (P-2) or the person who is told (P-3) should use the word subtle neda. Thus, the sentence (05) and (06) should have been disclosed as in sentence (07) and (08) here.

(07) Dupi Tétéh mulih ti mana?

'[My sister, where you come from?]'

(08) Dupi Bapa parantos tuang? '[Have you eaten?]'

Found also the users of Sundanese language uses the word polite childhood in talking with others as shown in the following data.

(09) Punten nya, abdi badé uih ti payun. '[Please excuse me, I want to go home first.]'

(10) Aduh abdi lapar pisan, ti énjing teu acan emam. '[Ouch I am hungry, since morning have not eaten.]'

On the data above seem the use of politeness language when speaking (P-1) communicating with partners said (P-2) using the word delicate infancy, i.e. words uih 'come back home" and emam 'eat' said. The word uih is short for the word mulih, which is fine for someone else's words. However, the word becomes a subtle Word uih childhood. The use of the word subtle in a sentence on the right is the word wangsul ' come back home ', i.e. a smooth words to yourself (P-1). The word emam is said smoother childhood, possibly a shortening of the word mamam. It should, in a sentence it's used the word subtle neda 'eat'. Thus, the sentence (09) and (10) can be corrected into a sentence (11) and (12).

There are problems in lexical politeness rule in Sundanese, namely the existence of a rant the same or different from the smooth words for yourself or for friends to talk and people talk about. This is resulting in the existence of the use of the words smooth for others (P-2 and P-3) is used for yourself. There are three lexical patterns that cause the problems of language politeness usage in Sundanese.
(a) The Pattern I: Rough (R)
$\neq \quad$ Respectful $(\mathrm{RP}-1) \quad=\operatorname{Respectful}(\mathrm{RP}-2$ or RP-3) (wa)wartos (wa)wartos ' tell' (bé)béja
(b) The Pattern II: Rough (R) lalaki$$
=\text { Respectful (RP-1) }
$$ lalaki
Respectful (RP-2 or RP-3) pameget 'man'
(c) The Pattern III: Rough (R) $\neq$ Respect anggeus réngsé parantos 2 or RP-3) ' completed '

The third pattern is found from 593 words of politeness language has a number of evenly distributed, i.e. the pattern I as many as 236 words $(39.80 \%)$, pattern II as much as 236 words $(39.80 \%)$, and pattern III as much as 121 words $(20.40 \%)$. The problem arises because there is a harsh word with the same Word $=$ Word respect for oneself as well as there are fine words to yourself the same or different from the smooth words for others (RP-2 and RP-3).

\section{The Value of Local Wisdom in the Sundanese Language Politeness}

The term "local wisdom" as the translation of "local genius", first introduced by Quantch Wales (1948-1949) with the meaning of "the progress of local culture in the face of foreign cultural influences at the time the two cultures It relates ".[8] Local wisdom can be 
understood as the ideas of the local which is full of wisdom, discernment, good value, embedded and followed by the member society. Local wisdom into the identity or personality of nation culture (cultural identity) so that the nation can afford to absorb and cultivate foreign cultures in accordance with figures and its own merits.[9] The local wisdom values are considered to be good and right so that it can survive in a long time and even work.[10] The existence of local wisdom is an element of the culture of the area, tested its ability to survive until now.

As the cultural elements that have proven their ability to survive, the Sundanese language politeness indicates the value of local wisdom. In politeness language implied the existence of attitudes and activities respect, either yourself or others. Public life indicated that people who respect others equal with respect for yourself. That is, when the communication language, people speak with utmost respect for yourself and for others, both partners said and told, showed that these people have respect for herself and others. This can be understood because language politeness has six function, i.e. the personal function, social functions, cultural function, educational function, integrative function, and instrumental functions.

The local wisdom values implied in the Sundanese language refers to the politeness values character education nation. There are four values character education nation which animates the local wisdom values of Sundanese politeness, namely (1) friendly or communicative, (2) the partnership, (3) peace, and (4) responsibility.

The value of friendly or politeness language communicative looks from behavior that always maintain good relations with positive interactions between members in the life of society. This behavior is manifested by using the language of polite as a tool to get along and communicate between speakers of the language. This is in line with the functions of language as a means of verbal communication. Communicative value of language politeness related to linguistic factors and non-linguistic. Related to it, language Sundanese politeness, commonly called smooth language (basa lemes) usage, language must be supported by four factors, namely (a) oral or 'words', (b) face expression (pasemon), (c) kinesics (réngkak jeung peta), and (d) the intonation (lentong).[11] Almost the same view expressed that linguistic politeness include (1) the length of the short speech, (2) the order of speech, (3) the intonation and gesture kinesik, and (4) wearing an expression of politeness marker. In a nutshell, the long syntax level sentence and order can affect speech politeness. Presented the following two marker of politeness sentence, namely (1) the order said, (2) the length of the speech, (3) an expression of politeness, and (4) the intonation.[12]

The value of teamwork in language politeness looks of behavior or actions that show cooperation with others. Reflection on the cooperation covers a few things, namely (a) when people are working together with shared objectives; (b) require the knowledge of the value of the participation of all individuals and how to maintain good attitude; (c) creating the will of good and pure feelings on fellow and the task at hand; (d) the need to find out what is needed; (e) the principle of mutual direkat by cherish; (f) receipt of cooperation; (g) where there is love, there is no saying cooperation; (h) the basics such as courage, consideration, maintenance, and share the profits; and (i) shall awareness values. [13] the details of cooperation is a reflection of values that are often encountered in the community who are committing yourself on a family, community, and working groups. The cooperation of the private train someone to always think for the sake of the benefits shared and shared success. The cooperative values in language politeness concerning the pattern of the relationship between language users. The parties involved in the speech was the speaker (I (P-1)), listener (P-2), and the spoken (P-3). Collaboration in the sociolinguistic rules relating to language, the seat of self and respect for others. Sekaitan with the position in language politeness there are several factors to consider, 
among other things, age, rank, degree of kinship, semat, blood degree, Bachelor's scholarship, and acquaintances.[14] This behavior is realized by using a variety of strong language, medium, and subtle variety of a language corresponds to the relationship between speakers, the partners said, and people who are spoken. For example:

(11) Kuring indit ka sakola.

'[I go to school.]'

(12) Abdi mios ka sakola

'[I go to school.]'

(13)
(The rough variety $\mathrm{P}-1$ )

(The smooth variety $\mathrm{P}-1$ )

(The smooth variety $\mathrm{P}-2 / \mathrm{P}-3$ )

The word of indit said 'go' belongs to the harsh words used by yourself (P-1) and others (P-2 or P-3) in an familiar and already know each other. The word 'go' mios belongs said subtle used for yourself (P-1) when talking with other people who need to be respected for his age, position, or social status. Foster said ' go ' used to talk friend (P-2) or people who are spoken of (P-3) in official situations and need to be respected for his age, position, or social status.

The value of peace in language politeness looks of attitudes, words, and actions that cause others to feel happy and secure over the presence of himself. The reflection of peace includes several things, namely (a) is not merely the absence of war; (b) growing from nonkekerasan, acceptance, fairness, and communication; (c) begins in each of our hearts; (d) if every person at peace, the world will be at peace; (e) proof of an act depends on the evidence of the person; (f) peace from within the containing the power of truth; (g) a mind that is pure, unadulterated feeling, and pure hope; (h) energy quality; (i) the compassion and strength; (j) Although there is still a State of tranquillity-of chaos; $(\mathrm{k})$ the main character of a civilized society; and (l) a quiet and serious reflection, new and creative ways are found to build understanding, friendship, and cooperation among all people. This behavior is manifested by using the language of polite with a facial are friendly, polite words, and intonation are taxable. Communication between speakers of the language will develop problems if not using language that is polite, friendly behavior and a facial, as well as the appropriate intonation.[15]

The value of an award in the language politeness related to attitudes and actions that encourage him to produce something useful for the community, recognize, and honor the success of others. The award is an important value in human life. Human desires are rewarded the existence and his strengths and weaknesses. Therefore, human beings must also appreciate the advantages, disadvantages, and the work of others. The current reality in the global era, culture to appreciate something tend to slump caused the high sentiment that impressed hegonis lifestyle so ignore values respect for ethical kehiduan of society. Reflections awards include a few things, namely that (a) every human being is precious, and part of self-esteem is know personal qualities; (b) when we value ourselves, it will be easy to appreciate another person; and (c) when there is a power of a humble in respect to other people, developing wisdom and we become fair and easy to adjust themselves against each other.[16]

In the use of politeness language implied the existence of an attitude to appreciate yourself, friends say, and people talk about. This appears to be from the use of the vocabulary chosen for yourself, friends, or talk to people who talk about. There are harsh words and the subtle words used for yourself the same but different with friends and talk to people who talk about. There are harsh words and the subtle words used for themselves different, but equal to the fine words to friends talk and people talk about. There is also a different rant with smooth words for yourself and for the fine words spoken partners or people who are spoken. Consider the following example! 
(14) Ari bapa iraha rék indit ka Jakarta téh?

'[When will you go to Jakarta?]'

In the example usage seems a harsh word for people who need to be respected. If there are people who speak rudely to others that need to be respected, then it can be inferred that people do not appreciate himself as well as others. Of course it will be different with the use of fine words while talking to the people who need to be respected. Compare the above example with the following example.

(15) Dupi bapa iraha badé angkat ka Jakarta téh?

'[When will you go to Jakarta?]'

The value of responsibility in language politeness related to the attitude and behavior of a person to perform the duties and obligations that should have been done to the self, society, environment (natural, social, cultural), country and The One Almighty God. Realize that all things were made by him is not only the duties and obligations for himself, but also the family, neighborhood, community, country, and God Almighty. Reflection on responsibility covers a few things, namely, (a) if we want peace, we are responsible for peace; (b) if we want a world that is clean, we are responsible for guarding it; (c) perform the tasks; (d) accepts the need and perform the tasks with their best; (e) perform the duty with a vengeance; (f) when in charge, there is satisfaction in its contribution; (g) have something of value to give; (h) figure out how to do justice; (i) the grant of the right; (j) an obligation and help achieve the goal; $(\mathrm{k})$ the observation of the world and the balance between rights and obligations; (l) in recognition of the whole human race; and (m) using the whole power for positive change. [17] in language politeness implied that the speakers of the languages already have a sense of responsibility, good against her country, society, or the Lord Almighty. This responsibility as the image of abiding principle in mingle and speak. People who hang out and speak not using the correct rule can be considered has no responsibility.

The era of the industrial revolution 4.0 is a continuation of the earlier Industrial Era, namely the industrial age, the industrial age 4.0 1.0, 2.0, the industrial age and the industrial age 3.0. The industrial age is marked with 4.0 Cyber Physical Systems, while the previous stage is the industrial age 3.0 marked with Computers and Automation, industry-2.0 Era characterized by Mass production, assembly line, and electricity, and the industrial age 1.0 characterized by Mechanization, Water Power, and Steam Power. The development of science and technology are so increasingly, including Indistri 4.0 Era, has a direct influence on life. The influence of different nature. At least developments that affect four areas, namely (1) directly to the field of intellectual property, leaving customs, or beliefs of traditional and new habits take; (2) the influence on industry and ability in Phoebe's war; (3) changes that was brought on social organizations gradually crept in the areas of political life; and (4) changes as well as collision against the tata group. Those things are all directly concerned or send it-joint human life and gradually has become a joint engagement. In the end determine the demise of mankind live in this world. To that end, it is necessary the preparation of more innovative learning system at colleges such as the readjustment of curriculum learning, and enhance the ability of the student in terms of data on Information Technology (IT), Operational Technology (OT), Internet of Things (IoT), and Big Data Analytic, integrating physical, digital objects and humans to produce college graduates who are competitive and skilled especially in the aspect of data literacy, technological literacy and human literacy. 
In the Era of industrial technology 4.0 many found the use of the language in the electronic and digital media, including in the use of the internet, email, socmed, Instagram, Whats the app, facebook, etc. Whatever the type of medium, the use of language politeness should pay attention to language. Because no matter how sophisticated the tools of communications technology, the medium is still the language used should pay attention to the rules and norms of politeness language. The following is an example of the use of language in the WhatsApp (WA) Group.

(01) Dedi: Tadi teu ngampus? Teu aya.

'[A while ago not to come to campus. I didn't see you.]'

Dede: Masih di Cimahi. Pun biang nu di Bojongsoang kamari ngantunkeun,

Bah! Pupusna di Cisarua.

'[I still exist in Cimahi. My mother who lives in Bojongsoang dead yesterday, Sir! He died in Cisarua]

Dedi: Innalillahi wainnailaihi raziun. Mugia almarhumah husnul khatimah.

'[Comes from God, returned to him. May the deceased ends well]'

Dian: Innalilahi wainailaihi rojiun... ngiring sungkawa Pa H. Dede.

'[Comes from God, returned to him. I join the grief, Mr. Dede.]'

Atun: Innalilahi wa innailaihi roji'un, mugi alm. husnul khotimah, tabah nya Pa Dede.

'[Comes from God, returned to him. May the deceased ends well. Hopefully the stoic Mr. Dede]'

Temmy: Mugia husnul khotimah. Abdi sarimbit ngiring sungkawa.

'[May the deceased ends well. Me and My family join the grief]'

Yayat: Innalillahi wa innailaihi raziun. Mugia almarhumah husnul khatimah.

Aamiin. (GWA Dosen Sunda UPI, 05032019).

'[Comes from God, returned to him. May the deceased ends well.

Ameen]' (Whats app Group Sundanese Lectures UPI, 05032019).

The example shows that the WhatsApp (WA) in the Era of the industrial revolution 4.0 use of Sundanese language must not violate etiquette or politeness language. Among Sundanese language users still heed an atmosphere of mutual respect as ethical description of a society that has a value of local wisdom.

In a community, i.e. in the WhatsApp Group of Language Clinic (Klinik Basa), found the use of words and word pairs uing. This obviously violates the Sundanese politeness. Word belongs into a smooth variety with the meaning 'belonging to the first person' to be followed by the words of kinship, as in the phrase 'my father' (pun bapa) and 'my grand mother' (pun nini). In the meantime, said uing pertained to in the range of rough with the meaning of ' I '. Also the mounting grammatical word and the word unacceptable uing (ungrammatical) because its meaning overlap, i.e. *pun uing '[*I owned my own]'.

This shows that in the Era of the industrial revolution 4.0 use of any language should be right, must not violate the rule, but it should obey the principle. The basic form of obedient that's visible from the use the correct language, i.e. the language usage in accordance with the rules of standard language, and the use of good language, i.e. the language usage in accordance with the context of the situation, lamguage politeness covered here.

\section{CONCLUSIONS}

Politeness language is one of the four types of etiquette, three types of etiquette is politeness appearance (dress up), politeness, politeness and socialization in the life of society. Politeness language, commonly called the tatakrama language, the system is the use of a 
variety of a language (lemes, sedeng, and coarse) with the relevant power (power), position (social status) and familiarity (solidarity), as well as the relationship between the roles of speakers and partners said.

There are two factors of language politeness, i.e. linguistic factors such as (1) vocabulary (lexico-semantical relations) and (2) the intonation (phonological) and non-linguistic factors such as (3) follow the horns (kinesik; gestures) and (4) a facial. In addition, there are also socio-pragmatic factors related to social interaction and context of the situation. Sundanese language politeness know the selection of words for speaker (P1), speaking partners ( $\mathrm{P} 2)$, and the third person spoken (P3). The selection of the polite word is determined by the position of the speakers of the language, the power, familiarity, and the relationships between the roles of speakers and speaking partners.

In Sundanese implied politeness five local wisdom values, based on the values of character education in the nation. The fifth such national character education value is (1) friendly/communicative, (2) the partnership, (3) peace, (4) and (5) responsibility. The use of language politeness refers to the use of language that is true and abiding principle, must not be violated, even in the Era of the industrial revolution 4.0. This is because language politeness educate users of the language are characteristic of good or have akhlakul karimah.

\section{REFERENCES}

[1] Y. Sudaryat, Wawasan Kesundaan. Bandung: JPBD FPBS UPI, 2015.

[2] A. . Keraf, Etika lingkungan hidup. Jakarta: Kompas Media Nusantara, 2002.

[3] E. Ochs, Planned and unplanned discourse. 1979.

[4] Samsuri, Analisis Bahasa. Jakarta: Erlangga, 1995.

[5] G. Leech, Principles of Pragmatics. London: Longman, 1983.

[6] K. et al Yudibrata, "Pengajaran Tatakrama Sunda" dalam Pendidikan Kebudayaan Sunda untuk SMA. Bandung: Sundanologi, 1986.

[7] Y. Sudaryat, "Kaidah Tatakrama Bahasa Sunda sebagai Acuan Pergaulan Mahasiswa." Bandung: LPPM UPI, 2015.

[8] A. Rosidi, Keraifan Lokal dalam Perspektf Budaya Sunda. Bandung: Kiblat, 2011.

[9] Haryati Soebadio dalam Sartini, "“Menggali Kearifan Lokal Nusantara: Sebuah Kajian Filsafati,", J. Filsafat, Jilid 37, no. 2, p. 111, 2009.

[10] Geriya dalam Sartini, "“Menggali Kearifan Lokal Nusantara: Sebuah Kajian Filsafati,"” J. Filsafat, Jilid 37, no. 2, p. 111, 2009.

[11] R. . Adiwidjaja, Adegan Basa Sunda. Djakarta: Groningen, 1951.

[12] R. K. Rahardi, Sosiolinguistik, Kode dan Alih Kode. Yogyakarta: Pustaka Pelajar, 2001.

[13] D. Tillman, Living Values: Activities for Children Ages 8-14. Jakarta: Gramedia, 2004.

[14] Hardiyanto, “Pemikiran Etik dalam Keselarasan Komunikasi Orang Jawa," J. Kebud. Jawa, vol. Edisi 3 Ta, p. 83, 2007.

[15] Tillman, Living Values: Activities for Children Ages 8-14. Jakarta: Gramedia, 2004.

[16] Tillman, Living Values: Activities for Children Ages 8-14. Jakarta: Gramedia, 2004.

[17] Tillman, Living Values: Activities for Children Ages 8-14. Jakarta: Gramedia, 2004. 